\title{
Spatial trends in community richness, diversity, and evenness across rocky intertidal environmental stress gradients in eastern Canada
}

\author{
Ricardo Scrosati* ${ }^{*}$ Christine Heaven \\ Saint Francis Xavier University, Department of Biology, Antigonish, Nova Scotia B2G 2W5, Canada
}

\begin{abstract}
An environmental stress model (ESM) developed by B. A. Menge and J. P. Sutherland and improved by other researchers predicts how local-scale richness and diversity (terms often used interchangeably in previous ESM research) should vary with environmental stress. We tested model predictions by surveying all benthic producers and consumers across vertical (elevation) and horizontal (wave/ice exposure) stress gradients in rocky intertidal habitats from the Gulf of St. Lawrence (which freezes in winter) and open Atlantic (which does not freeze) coasts of Nova Scotia, Canada. Since local winter conditions are harsher than on most temperate shores studied previously, we made predictions for an intermediate-to-high range of stress: richness and diversity would be lowest in highly stressful habitats and would increase with decreasing stress. Results matched predictions across vertical gradients on both coasts (richness and diversity were negatively related to elevation) and across horizontal gradients on the Gulf coast (richness and diversity were negatively related to wave/ice exposure) but not entirely on the Atlantic coast (richness was negatively related to wave exposure, but diversity showed an opposite trend). The spatial changes in evenness explained such differing trends in richness and diversity. Richness and diversity were higher on the Atlantic than on the Gulf of St. Lawrence coast, consistent with the stronger physical stress (winter ice scour) on the Gulf coast. Our study indicates that richness and diversity may respond differently to local-scale environmental stress, contrary to common assumptions. To determine the conditions under which such differences might occur, future ESM studies should investigate both variables and also evenness, which together with richness determines diversity.
\end{abstract}

KEY WORDS: Diversity - Elevation - Environmental stress gradient · Evenness · Ice scour · Richness · Rocky intertidal · Wave exposure

Resale or republication not permitted without written consent of the publisher

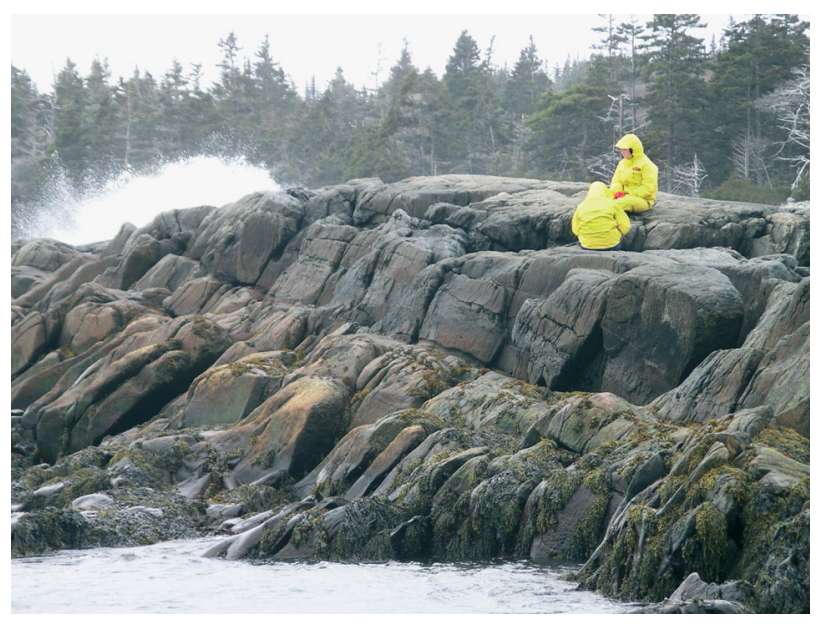

Atlantic coast of Nova Scotia at low tide.

Photo: Ricardo Scrosati

\section{INTRODUCTION}

Species diversity is one of the most important traits of a community, because diversity is related to productivity, stability, and susceptibility to invasion (Hooper et al. 2005, Worm et al. 2006). Thus, studies aiming to understand spatial trends in diversity have been frequent in ecology. Diversity (also referred to as heterogeneity) relates to the probability that 2 randomly selected individuals in the community belong to different species. As such, diversity depends on 2 different measures of community structure: richness, which is the number of species in the community, and evenness, which is the degree of similarity in abundance among species (Krebs 1999). 
Environmental stress is thought to play a major role in determining local-scale community diversity through interactive effects with interspecific interactions (Menge et al. 2002, Crain \& Bertness 2006). Knowledge in this area has frequently accumulated by using rocky intertidal habitats as model systems, since the pronounced environmental gradients that occur across short distances, together with the relatively small size of intertidal organisms, facilitate observational and experimental research (Menge \& Branch 2001). Stress gradients are most pronounced vertically, since desiccation, temperature, irradiance, and osmotic stresses intensify with elevation because of increasing aerial exposure due to tides (Raffaelli \& Hawkins 1996, Garbary 2007). On a horizontal basis, environmental stress gradients occur because of changes in wave exposure (Denny \& Wethey 2001) and, in polar and subpolar shores, ice scour intensity (Barnes 1999, Gutt 2001).

The spatial relationships between local-scale diversity and environmental stress described for rocky shores have often resulted from combining observations on different subsets of organisms done for different shores, seasons, and years. Rarely have studies considered simultaneously all species across full environmental stress gradients on the same shore (see Lubchenco et al. 1984, for an example across elevation). Such an approach would represent a powerful test of predictions about diversity. For this reason, we examined local-scale trends in diversity across vertical (elevation) and horizontal (wave/ice exposure) rocky intertidal environmental stress gradients. Past studies often considered diversity and richness as synonyms (Menge \& Sutherland 1987, Paine 1994, Hacker \& Gaines 1997, Bertness 2007), but their respective spatial trends may differ because diversity depends on richness and evenness (Krebs 1999, Kimbro \& Grosholz 2006). Thus, we also examined trends in richness and evenness. We performed our study on 2 environmentally different coasts in Nova Scotia (Canada): the Gulf of St. Lawrence coast and the open Atlantic coast.

An environmental stress model (ESM) predicts how the diversity (or richness; the terms have been used interchangeably) of basal species in local communities should vary across the full environmental stress gradient in which a basic set of species can occur (see Fig. 5 in Menge \& Sutherland 1987). Unimodal diversity patterns across the full stress gradient are predicted under low recruitment rates of basal species or under high rates when niche partitioning facilitates species coexistence. A bimodal diversity pattern is predicted under high recruitment rates when competitive exclusion of basal species occurs at intermediate stress levels. For all cases, the low diversity predicted at the highest and lowest stress levels results from intense abiotic stress and intense predation, respectively. The left half of
Menge \& Sutherland's (1987) bimodal curve (note that they plotted a reversed $x$-axis in their Fig. 5) represented the intermediate-disturbance hypothesis (disturbance being an extreme form of stress); this hypothesis stated that diversity peaks at intermediate disturbance levels because high abiotic stress and competitive exclusions limit diversity at high and low disturbance levels, respectively. The right half of Menge \& Sutherland's (1987) bimodal diversity curve represented the predation hypothesis, which stated that diversity peaks at intermediate predation levels because competitive exclusions and predatory exclusions limit diversity at low and high predation levels, respectively; predation levels were assumed to increase with decreasing stress.

Recent studies have incorporated positive interactions (mutualism and commensalism) into the ESM, and also consider other species than basal to make diversity predictions (Hacker \& Gaines 1997, Bruno et al. 2003, Hay et al. 2004, Wright et al. 2006). In such an updated model, the competitive exclusion of primaryspace holders is not detrimental to overall diversity, because competitively dominant species provide habitat conditions for a number of secondary species that would otherwise not exist locally. In other words, community diversity often peaks at low levels of disturbance and predation, and is lowest at high disturbance and predation levels (see Fig. 1d-ii in Bruno et al. 2003). Joining the 2 updated 'halves' of the ESM, now considering facilitations and overall diversity (not just the diversity of basal species), competitive exclusions occurring at intermediate stress levels lead to a unimodal diversity pattern across the full environmental stress gradient (Fig. 1). Community diversity on rocky shores is also known to vary with nearshore nutrient concentration and the resulting effects on the productivity of benthic basal species. However, the nutrient-productivity model describing such relationships applies more to regional spatial scales (Menge 2004); thus, it was not applicable to the local scales of our study.

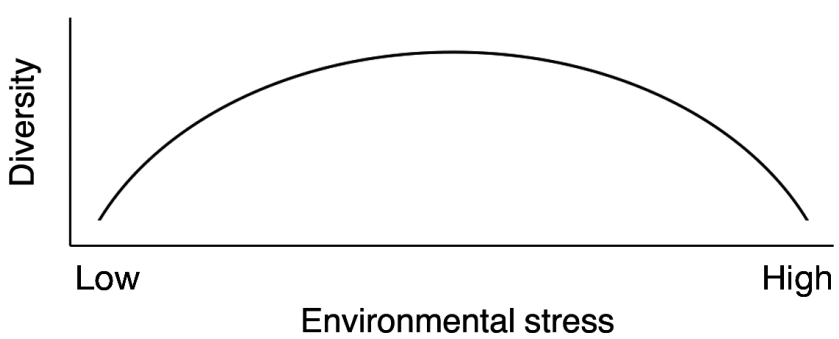

Fig. 1. Predicted pattern for community diversity across the full environmental stress gradient in which a basic set of species can occur. This model results from modifications by Bruno et al. (2003) to a model by Menge \& Sutherland (1987). See 'Introduction' for details 
To make predictions on richness and diversity for Nova Scotia shores, we used the latest ESM version (Bruno et al. 2003; our Fig. 1), which considers both variables to be equivalent. The full environmental range across which a regional pool of species exists rarely occurs locally on the same shore (Menge \& Sutherland 1987). Rocky intertidal communities in Nova Scotia include the same basic set of seaweeds and invertebrates as New England (Adey \& Hayek 2005), where much of the research on the ESM has been done (see references in Menge \& Branch 2001, Bertness et al. 2004). However, latitudinal differences determine that winter conditions are harsher in Nova Scotia than in New England (Bertness 2007). Thus, our study sites would not include year-round mild environmental conditions, at least not as mild as in New England.

We made predictions separately for the vertical and horizontal environmental gradients. Because of its strong abiotic stress (Menge \& Branch 2001, Garbary 2007), we considered the high intertidal zone to represent the high end of the environmental stress gradient across elevation; abiotic stress decreases towards lower elevations (Raffaelli \& Hawkins 1996). Thus, according to the revised ESM (Bruno et al. 2003; our Fig. 1) and under the assumption that low levels of year-round stress do not occur in Nova Scotia, we hypothesized that diversity and richness would increase from the high to the low intertidal zone at our sites. Across horizontal gradients on rocky shores, different abiotic stresses vary in opposite ways. At any given elevation, physical stress increases with wave exposure (Denny \& Wethey 2001), but physiological stress due to desiccation, temperature, irradiance, and osmotic effects increases towards sheltered habitats because of less frequent splash at low tide (Menge \& Branch 2001). For our sites on the open Atlantic coast, we wanted to focus on the physical stress gradient generated by wave action, so we used an indicator species (barnacle) to determine elevation ranges with similar emersion-related stresses for shore areas differing in wave exposure (see 'Materials and methods'). According to the current ESM (Bruno et al. 2003; our Fig. 1), and considering that our wave-exposed sites faced the Atlantic Ocean directly, we hypothesized that richness and diversity would be negatively related to wave exposure. Although we sampled sites with the lowest wave exposure that we could detect, rocky sites in very protected areas (enclosed bays) show even lower exposures, so for our open-coast sites we made no predictions for low stress levels as shown in Fig. 1. Unlike the open Atlantic, the Gulf of St. Lawrence freezes extensively in winter (Saucier et al. 2003), causing severe ice scour on intertidal habitats (Scrosati \& Heaven 2006). Wave exposure and ice scour intensity are spatially correlated on the Gulf of St. Lawrence coast, signaling a higher year-round stress on exposed than on sheltered habitats. Thus, we hypothesized that richness and diversity would be negatively related to wave/ice exposure. Because of the predictable occurrence of ice scour every winter, for the Gulf of St. Lawrence coast we made no predictions for low stress levels.

Predicting evenness trends was more difficult, as this component of diversity has been overlooked in ESM studies (Kimbro \& Grosholz 2006). It is conceivable that, under high stress, evenness is low because only a small fraction of all present species would be able to do relatively well, the remaining few species being scarce. As stress decreases, the latter species would increase in abundance, so evenness would increase as a result. Thus, we hypothesized that evenness would increase from the highest to the lowest levels of environmental stress occurring on the Gulf of St. Lawrence and open Atlantic coasts of Nova Scotia.

\section{MATERIALS AND METHODS}

Study sites. Our study sites in Nova Scotia were Sea Spray Shore $\left(45^{\circ} 46^{\prime} \mathrm{N}, 62^{\circ} 09^{\prime} \mathrm{W}\right.$; hereafter SS), on the Gulf of St. Lawrence coast near Arisaig, and Tor Bay Provincial Park $\left(45^{\circ} 11^{\prime} \mathrm{N}, 61^{\circ} 21^{\prime} \mathrm{W}\right.$; hereafter TB), on the open Atlantic coast. Based on preliminary biological surveys done for several sites along $500 \mathrm{~km}$ of coastline, we found that SS and TB are representative sites for the Gulf of St. Lawrence and open Atlantic coasts, respectively, of our latitudinal range in Nova Scotia (Heaven 2006). We restricted surveys to rocky intertidal sites with stable bedrock, which consisted of volcanic rock at SS and metamorphose sedimentary rock at TB. Both sites have similar degrees of substrate rugosity. Surface seawater temperature (SST) ranges between monthly averages of -1.4 to $18.2^{\circ} \mathrm{C}$ in the SS region and -0.3 to $16.9^{\circ} \mathrm{C}$ in the $\mathrm{TB}$ region, while surface seawater salinity ranges between monthly averages of 28.4 to $30.6 \%$ in the SS region and 29.5 to $31.4 \%$ in the TB region (Fisheries and Oceans Canada 2007a). Between the summer and autumn of 2005, we recorded a maximum SST of $21^{\circ} \mathrm{C}$ at SS (August) and $20.5^{\circ} \mathrm{C}$ at $\mathrm{TB}$ (September) and a maximum surface seawater salinity of $32 \%$ at SS (October-November) and $35 \%$ at TB (October).

Environmental stress gradients. We investigated the entire vertical (elevation) and horizontal (wave exposure and/or ice scour) gradients of environmental stress that can be found on the Gulf of St. Lawrence and open Atlantic coasts of Nova Scotia.

Elevation (vertical): In intertidal habitats, the vertical gradient in emersion time determines, directly or indirectly, vertical zonation patterns in species compo- 
sition (Menge \& Branch 2001). Wave action extends biological zones upwards by reducing the duration of emersion at any given elevation (Raffaelli \& Hawkins 1996, Harley \& Helmuth 2003). Thus, the same elevation is not the best reference at which to compare species assemblages subjected to similar emersion stresses between areas differing in wave exposure. For this reason, for the different exposure levels we considered (see below), we determined the upper boundary of the intertidal zone by determining the upper distribution boundary of the barnacle Semibalanus balanoides. This organism represents the highest sessile, perennial species anywhere at SS and TB (Heaven 2006), which ensured that annual and seasonal wave regimes were integrated when determining upper intertidal boundaries. For each exposure area, we measured the elevation of the highest barnacles on emergent rocky surfaces (excluding crevices) using an extensible pole and a sighting scope. Then, we divided the intertidal zone into 3 equal sections (high, mid-, and low zones), marking the limits of each with nails secured to rocky surfaces with marine epoxy (A-788 Splash Zone Compound, Z-Spar). Shore sections with less than a $40^{\circ}$ slope or low substrate rugosity were avoided for consistency. Thus defined, the upper intertidal boundary, relative to chart datum $(0 \mathrm{~m})$, was 1.66 $\mathrm{m}$ (wave sheltered) and $1.70 \mathrm{~m}$ (wave exposed) at SS, and $1.56 \mathrm{~m}$ (wave sheltered), $1.99 \mathrm{~m}$ (intermediate exposure) and $2.16 \mathrm{~m}$ (wave exposed) at TB.

Wave exposure (horizontal): Wave exposure levels were determined through observations of breaking wave heights in 2004 and 2005. The exposure gradient on the southern Gulf of St. Lawrence coast is narrower and lower than on the Atlantic coast (Fisheries and Oceans Canada 2007b). Thus, 2 exposure levels were selected for SS (sheltered and exposed) and 3 for TB (sheltered, intermediate, and exposed). Sheltered sites were protected by offshore islets, while exposed sites faced open waters directly; intermediate exposure resulted from clusters of islets partially blocking waves. To quantitatively assess our site selections, we measured wave exposure in terms of maximum water velocity between 20 August and 25 November 2005. In three $24 \mathrm{~h}$ trials within this period, we deployed 4 spring-loaded dynamometers (Bell \& Denny 1994) per exposure level by attaching them to the substrate with hooks and epoxy. The dynamometers were placed in areas free of crevices and the substrate around each dynamometer was cleared of seaweeds to prevent entanglement. The maximal extension of the spring during a $24 \mathrm{~h}$ trial occurs when the strongest wave hits the shore; this extension is automatically recorded by a rubber indicator inside the dynamometer. The maximal extension was noted when dynamometers were collected and then applied to a formula (see Bell \&
Denny 1994) to calculate maximum water velocity. We used springs with a spring constant of $830 \mathrm{~N} \mathrm{~m}^{-1}$ and an initial tension of $4.45 \mathrm{~N}$.

Ice scour (horizontal): Significant ice scour occurs only on the Gulf of St. Lawrence coast at our latitudes in Nova Scotia. Sea ice forms in early winter and melts between late winter and early spring (Saucier et al. 2003). Measurement of the damage caused by sea ice to metallic cages that were affixed to rocky surfaces for an entire winter at SS indicated that ice scour is strong on wave-exposed areas and milder on wave-sheltered areas (Scrosati \& Heaven 2006; Fig. 2). Therefore, the 2 levels used for wave exposure at SS also represented differences in ice scour intensity. For simplicity, for SS the term 'exposed' will refer to high levels of wave exposure and ice scour, whereas the term 'sheltered' will refer to low levels.

Species abundance. Between 8 July and 21 August 2005 (when local richness was highest), we measured the abundance of all seaweeds and benthic invertebrates for each combination of elevation and exposure (6 combinations for SS and 9 for TB). For each combination, we determined the percent cover of species for twenty $625 \mathrm{~cm}^{2}(25 \times 25 \mathrm{~cm})$ quadrats that were randomly distributed across the rocky surface. The sampling device was a metallic frame with 100 divisions created with monofilament line. We chose percent cover to quantify abundance because alternative measures (e.g. density of individuals) cannot always be determined reliably for clonal organisms (Scrosati 2005) or (e.g. biomass) would have required destructive sampling of numerous shore areas. We identified species using field guides (Gibson 2003, Martínez 2003) and taxonomic keys (Pollock 1998, Sears 1998, Villalard-Bohnsack 2003). For very small species and for related species showing phenotypic overlaps in morphology, the accurate field identification of organisms at the species level is virtually impossible. For the few such cases, we measured cover for the lowest possible taxonomic level, as done normally by studies that document diversity considering all producers and consumers simultaneously (Kimbro \& Grosholz 2006, Russell et al. 2006). We excluded tide pools from samplings. If a species was present but its cover was less than $1 \%$, it was recorded as $0.5 \%$.

Richness, diversity, and evenness. We calculated richness, diversity, and evenness for each quadrat. Richness $(S)$ was the total number of species for the quadrat. Diversity was measured with Simpson's diversity index $(1-D)$ :

$$
1-D=1-\Sigma\left(p_{i}\right)^{2}
$$

where $p_{i}$ is the proportion of taxon $i$ in the quadrat. Proportions were calculated using percent cover data. Simpson's diversity index ranges between 0 and al- 

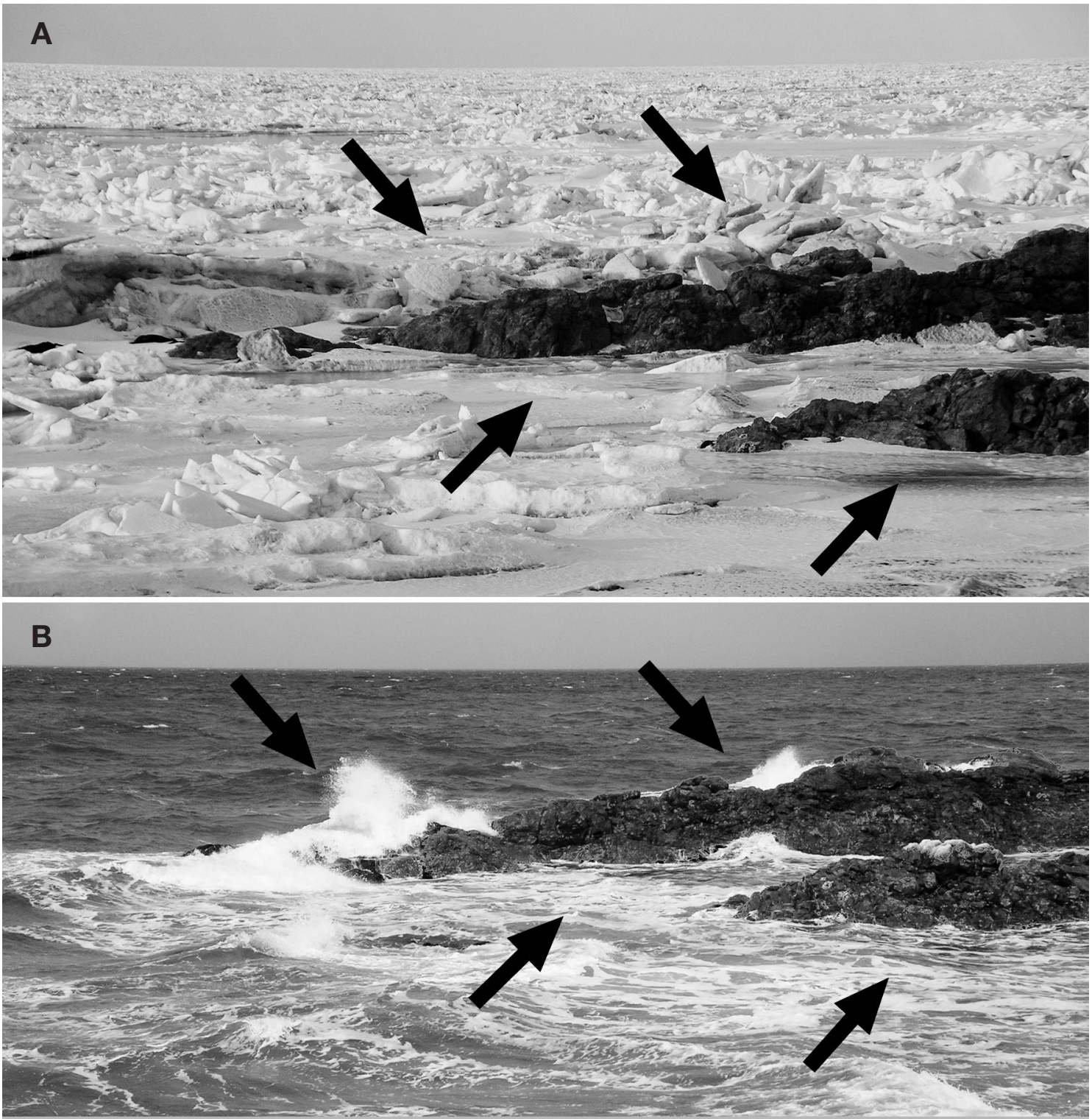

Fig. 2. Horizontal environmental gradient (wave/ice exposure) at Sea Spray Shore. (A) Winter view, showing areas exposed to strong (upper arrows) and mild (lower arrows) ice scour. (B) Spring view, showing areas exposed to high (upper arrows) and low (lower arrows) wave action. (Photos: R. Scrosati)

most $1\left(1-S^{-1}\right)$, is a robust diversity index, and has a low bias towards the abundance distribution and sample size (Krebs 1999). Evenness was calculated using Simpson's evenness index:

$$
E_{1 / D}=\frac{1 / D}{S}
$$

Simpson's evenness index ranges between 0 and 1 and is relatively unaffected by the rare species in the quadrat and by spatial distribution (Krebs 1999, Payne et al. 2005).

Data analysis. We compared maximum water velocity between exposure levels with a $t$-test for SS and with a 1-way analysis of variance (ANOVA) followed by Tukey Honestly Significant Difference (HSD) tests for TB. We tested the effects of elevation and exposure on richness, diversity, and evenness with separate 2-way, fixed-model ANOVAs. Elevation had 3 levels (low, mid- and high) at SS and TB, while exposure had 2 levels (sheltered and exposed) at SS and 3 levels (sheltered, intermediate, and exposed) at TB. Both factors were considered fixed because all levels were chosen a priori, every level of interest was included and the conclusions from the study were confined to such levels (Bennington \& Thayne 1994). Before testing the normality and homoscedasticity assumptions, 
we identified and removed outliers within cells using boxplots (Howell 2002). We tested normality within cells with Kolmogorov-Smirnov tests and homogeneity of variance among cells with Levene's tests (Quinn \& Keough 2002). Both assumptions were met in all cases.

When a 2-way ANOVA revealed main and/or interaction effects, we did post hoc tests. When a main effect (elevation or exposure) was significant, we tested pairwise comparisons between factor levels with Tukey HSD tests. When the elevation $\times$ exposure interaction was significant, we ran 1-way ANOVAs followed by Tukey HSD tests to test for simple effects (differences in elevation effects among exposure levels and differences in exposure effects among the 3 elevations). To compute the $F$ statistic for each simple effect, we used the error term from the 2-way ANOVA rather than from each 1-way ANOVA (Howell 2002, Quinn \& Keough 2002). Finally, we calculated the magnitude of experimental effect $\left(\omega^{2}\right)$ for each source of variation (elevation, exposure, and elevation $\times$ exposure interaction) whenever they were significant (Howell 2002).

\section{RESULTS}

\section{Wave exposure at SS and TB}

Measurements of maximum water velocity confirmed our visual assessment of exposure levels. At SS, maximum water velocity was higher $(t=3.65, \mathrm{p}<0.01)$ on exposed shore areas $\left(5.2 \pm 0.5 \mathrm{~m} \mathrm{~s}^{-1}\right.$, mean $\pm \mathrm{SE}_{\text {; }}$ range $=3.9$ to $\left.8.1 \mathrm{~m} \mathrm{~s}^{-1}\right)$ than on sheltered areas $(3.4 \pm$ $0.1 \mathrm{~m} \mathrm{~s}^{-1}$; range $=2.9$ to $4.1 \mathrm{~m} \mathrm{~s}^{-1}$ ). At TB, maximum water velocity differed between exposed, intermediateexposure, and sheltered areas $\left(F_{2,24}=14.4 ; \mathrm{p}<0.001\right)$. Mean maximum water velocity was lower on sheltered areas $\left(4.3 \pm 0.2 \mathrm{~m} \mathrm{~s}^{-1}\right.$; range $=3.2$ to $\left.5.6 \mathrm{~m} \mathrm{~s}^{-1}\right)$ than on intermediate-exposure $\left(6.5 \pm 0.6 \mathrm{~m} \mathrm{~s}^{-1} ;\right.$ range $=3.9$ to $\left.8.8 \mathrm{~m} \mathrm{~s}^{-1} ; \mathrm{p}<0.005\right)$ and exposed $\left(7.5 \pm 0.5 \mathrm{~m} \mathrm{~s}^{-1}\right.$; range $=6.1$ to $8.6 \mathrm{~m} \mathrm{~s}^{-1} ; \mathrm{p}<0.001$ ) areas. Mean maximum water velocity did not differ between intermediate-exposure and exposed areas $(\mathrm{p}=0.287)$, but strong waves were more frequent on exposed areas.

\section{Richness, diversity, and evenness at SS}

\section{Richness}

We identified 38 taxa (20 seaweeds and 18 invertebrates) at SS (Table 1). Richness varied across elevation $\left(F_{2,110}=54.95, \mathrm{p}<0.001\right)$. Combining both exposure levels, richness was lower at the high elevation than at the mid- $(p<0.001)$ and low ( $p<0.001)$ elevations, while it did not differ $(p=0.800)$ between the mid- and low elevations (Fig. 3A). Richness also varied between exposure levels $\left(F_{1,110}=27.14, \mathrm{p}<0.001\right)$. Combining the 3 elevations, richness was lower $(p<0.001)$ on exposed areas than on sheltered areas (Fig. 3B). The elevation $\times$ exposure interaction was also significant $\left(F_{2,110}=13.69, \mathrm{p}<0.001\right)$. Richness differed among elevations for both exposure levels (exposed: $F_{2,110}=13.01$, $\mathrm{p}<0.05$; sheltered: $\left.F_{2,110}=56.03, \mathrm{p}<0.05\right)$. On exposed and sheltered areas, richness was lower at the high than at the mid- $(p<0.01)$ and low $(p<0.001)$ intertidal zones (Fig. 4A). Richness was lower on exposed areas than on sheltered areas at the mid- and low intertidal zones (mid: $F_{1,110}=50.48, \mathrm{p}<0.05$; low: $F_{1,110}=4.63, \mathrm{p}<$ $0.05)$ and was similar at the high intertidal zone $\left(F_{1,110}=\right.$ 0.03 , $p>0.05$; Fig. 4A). The contribution of elevation, exposure, and the elevation $\times$ exposure interaction to the total variability in richness was $39.3 \%, 9.5 \%$, and $9.3 \%$, respectively ( $58.1 \%$ in total)

\section{Diversity}

Diversity varied across elevation $\left(F_{2,92}=277.23\right.$, $\mathrm{p}<0.001)$. Combining both exposure levels, diversity showed a monotonic increase $(p<0.001)$ from the high to the low elevations (Fig. 3C). Diversity also varied between exposure levels $\left(F_{1,92}=79.41, \mathrm{p}<0.001\right)$. Combining the 3 elevations, diversity was lower $(\mathrm{p}<0.001)$ on exposed areas than on sheltered areas (Fig. 3D). The elevation $\times$ exposure interaction was also significant $\left(F_{2,92}=79.50, \mathrm{p}<0.001\right)$. Diversity differed among elevations for both exposure levels (exposed: $F_{2,92}=$ 138.00, $\mathrm{p}<0.05$; sheltered: $F_{2,92}=194.63, \mathrm{p}<0.05$ ). On exposed and sheltered areas, diversity was lower at the high than at the low intertidal zone $(\mathrm{p}<0.001)$, with intermediate values at the mid-intertidal zone (Fig. 4B). Diversity was lower on exposed areas than on sheltered areas only at the mid- and low intertidal zones (mid: $F_{1,92}=231.25, \mathrm{p}<0.05$; low: $\left.F_{1,92}=5.88, \mathrm{p}<0.05\right)$, being similar at the high intertidal zone $\left(F_{1,92}=3.88, \mathrm{p}>0.05\right.$; Fig. 4B). The contribution of elevation, exposure, and the elevation $\times$ exposure interaction to the total variability in diversity was $61.2 \%, 8.7 \%$, and $17.4 \%$, respectively $(87.3 \%$ in total).

\section{Evenness}

Evenness varied across elevation $\left(F_{2,102}=5.06, \mathrm{p}=\right.$ 0.008). Combining both exposure levels, evenness was similar between the high and mid-elevations $(p=0.359)$ and between the high and low elevations $(p=0.171)$, but was lower $(p<0.005)$ at the mid- than at the low elevation (Fig. 3E). Evenness also varied between exposure levels $\left(F_{1,102}=9.17, \mathrm{p}=0.003\right)$. Com- 
Table 1. Abundance of taxa (percent cover $\pm \mathrm{SE} ; \mathrm{n}=20$ quadrats) across the elevation gradient (low, mid-, and high intertidal zones) on sheltered and exposed areas at Sea Spray Shore. Blanks represent zero abundance

\begin{tabular}{|c|c|c|c|c|c|c|}
\hline \multirow{2}{*}{ Taxon } & \multicolumn{3}{|c|}{ - Sheltered } & \multirow[b]{2}{*}{ Low } & \multicolumn{2}{|c|}{ Exposed } \\
\hline & Low & Mid & High & & Mid & High \\
\hline Seaweeds & & & & & & \\
\hline Ascophyllum nodosum & $26.63 \pm 7.88$ & $46.45 \pm 8.85$ & $5.5 \pm 1.81$ & $0.03 \pm 0.03$ & $0.43 \pm 0.16$ & $0.25 \pm 0.16$ \\
\hline Calothrix sp. & & $0.03 \pm 0.03$ & & & & \\
\hline Ceramium sp. & & $0.05 \pm 0.05$ & & $0.05 \pm 0.05$ & & \\
\hline Chondrus crispus & $18.25 \pm 3.92$ & $1.7 \pm 0.58$ & & $11.05 \pm 2.4$ & $0.23 \pm 0.08$ & \\
\hline Chorda filum & & & & $0.5 \pm 0.5$ & & \\
\hline Chordaria flagelliformis & $0.68 \pm 0.34$ & & & $35.3 \pm 9.33$ & $0.78 \pm 0.65$ & \\
\hline Cladophora sp. & & $0.05 \pm 0.05$ & & $0.05 \pm 0.03$ & $0.2 \pm 0.07$ & \\
\hline Corallina officinalis & $0.03 \pm 0.03$ & & & $0.05 \pm 0.03$ & & \\
\hline Dictyosiphon sp. & & $0.05 \pm 0.05$ & $0.05 \pm 0.05$ & & & \\
\hline Epiphytic brown algae & $2.3 \pm 0.69$ & $11.48 \pm 3.02$ & $0.73 \pm 0.65$ & $15.93 \pm 7.69$ & $1.1 \pm 0.52$ & $0.03 \pm 0.03$ \\
\hline Fucus serratus & $68.05 \pm 6.7$ & $17 \pm 5.05$ & & $6.68 \pm 3.06$ & & \\
\hline Fucus sp. & & $4.05 \pm 0.98$ & $4.48 \pm 2.81$ & $3.25 \pm 1.15$ & $5 \pm 1.32$ & $0.73 \pm 0.16$ \\
\hline Fucus vesiculosus & $4.25 \pm 2$ & $36.25 \pm 8.93$ & $5.25 \pm 3.65$ & & & \\
\hline Green crust & & $0.85 \pm 0.8$ & & & & \\
\hline Lithothamnion sp. & $5.98 \pm 2.09$ & $0.03 \pm 0.03$ & & $0.48 \pm 0.2$ & & \\
\hline Petalonia fascia & & & & $0.65 \pm 0.46$ & & \\
\hline Polysiphonia sp. & $0.63 \pm 0.55$ & $0.45 \pm 0.14$ & $0.18 \pm 0.08$ & $0.98 \pm 0.33$ & $0.18 \pm 0.05$ & \\
\hline Red crust & $9.3 \pm 3.81$ & $7.63 \pm 1.58$ & $0.75 \pm 0.52$ & $7.98 \pm 2.78$ & $1.08 \pm 0.56$ & $0.15 \pm 0.05$ \\
\hline Scytosiphon sp. & $0.03 \pm 0.03$ & & & $4.78 \pm 1.31$ & $3.23 \pm 1.64$ & \\
\hline Spongomorpha aeruginosa & & & & $0.1 \pm 0.06$ & & \\
\hline Invertebrates & & & & & & \\
\hline Amphipoda & $0.28 \pm 0.06$ & $0.5 \pm 0.06$ & $0.13 \pm 0.05$ & $0.28 \pm 0.07$ & $0.25 \pm 0.06$ & $0.23 \pm 0.06$ \\
\hline Asterias sp. & $0.05 \pm 0.05$ & $0.13 \pm 0.07$ & & $0.05 \pm 0.05$ & & \\
\hline Cancersp. & $0.25 \pm 0.25$ & $0.05 \pm 0.05$ & & & & \\
\hline Clava multicornis & $0.13 \pm 0.06$ & & & & & \\
\hline Crassostrea virginica & & $0.05 \pm 0.03$ & & & & \\
\hline Dynamena pumila & $8.85 \pm 2.62$ & $0.58 \pm 0.16$ & $0.03 \pm 0.03$ & & & \\
\hline Idotea sp. & & $0.1 \pm 0.05$ & & & & $0.03 \pm 0.03$ \\
\hline Littorina littorea & $0.43 \pm 0.12$ & $2.45 \pm 0.44$ & $0.45 \pm 0.12$ & $1.03 \pm 0.2$ & $0.63 \pm 0.1$ & $0.33 \pm 0.05$ \\
\hline Littorina obtusata & $0.35 \pm 0.08$ & $1.2 \pm 0.18$ & $0.13 \pm 0.05$ & $0.03 \pm 0.03$ & $0.08 \pm 0.04$ & $0.08 \pm 0.04$ \\
\hline Littorina saxatilis & & $0.05 \pm 0.03$ & $0.33 \pm 0.08$ & & $0.13 \pm 0.05$ & $0.53 \pm 0.03$ \\
\hline Membranipora sp. & $1.15 \pm 0.28$ & $0.2 \pm 0.11$ & & $0.15 \pm 0.11$ & & \\
\hline Mytilus sp. & $1.13 \pm 0.29$ & $4.03 \pm 0.76$ & $3.25 \pm 1.41$ & $6.73 \pm 1.7$ & $8.9 \pm 1.75$ & $1.35 \pm 0.46$ \\
\hline Nucella lapillus & & $0.28 \pm 0.08$ & & $0.03 \pm 0.03$ & $0.1 \pm 0.06$ & $0.03 \pm 0.03$ \\
\hline Obelia sp. & $0.03 \pm 0.03$ & $0.7 \pm 0.2$ & $0.2 \pm 0.2$ & & & \\
\hline Pagurus sp. & $0.05 \pm 0.03$ & & & $0.03 \pm 0.03$ & & \\
\hline Semibalanus balanoides & $30.48 \pm 6.56$ & $54.35 \pm 7.72$ & $56.15 \pm 8.2$ & $60.93 \pm 7.63$ & $79.05 \pm 3.09$ & $34.28 \pm 6.45$ \\
\hline Tectura testudinalis & $0.03 \pm 0.03$ & $0.13 \pm 0.06$ & & & & \\
\hline Worms & $0.03 \pm 0.03$ & $0.15 \pm 0.07$ & $0.03 \pm 0.03$ & $0.05 \pm 0.05$ & & $0.05 \pm 0.03$ \\
\hline
\end{tabular}

bining the 3 elevations, evenness was lower $(\mathrm{p}<0.01)$ on exposed areas than on sheltered areas (Fig. 3F). The elevation $\times$ exposure interaction was not significant $\left(F_{2,102}=0.42, \mathrm{p}=0.659\right)$. The contribution of elevation and exposure to the total variability in diversity was $6.6 \%$ in both cases $(13.2 \%$ in total).

\section{Richness, diversity, and evenness at TB}

\section{Richness}

We identified 58 taxa (30 seaweeds and 28 invertebrates) at TB (Table 2). Richness varied across elevation $\left(F_{2,150}=89.73, \mathrm{p}<0.001\right)$. Combining the 3 exposure levels, richness was lower at the high than at the mid- $(p<0.001)$ and low $(p<0.001)$ intertidal zones, while it did not differ ( $p=0.068$ ) between the midand low zones (Fig. 5A). Richness also varied among exposure levels $\left(F_{2,150}=26.23, \mathrm{p}<0.001\right)$. Combining the 3 elevations, richness was lower on intermediateexposure $(p<0.001)$ and exposed $(p<0.001)$ areas than on sheltered areas, while it did not differ $(\mathrm{p}=$ 0.325 ) between intermediate-exposure and exposed areas (Fig. 5B). The elevation $\times$ exposure interaction was also significant $\left(F_{4,150}=10.53, \mathrm{p}<0.001\right)$. Richness differed among elevations for the 3 exposure levels (exposed: $F_{2,150}=18.06, \mathrm{p}<0.05$; intermediate: $F_{2,150}=$ 78.98, p < 0.05; sheltered: $\left.F_{2,150}=16.44, \mathrm{p}<0.05\right)$. For the 3 exposure levels, richness was always lower at the high intertidal zone that at the low zone $(p<0.001)$, with intermediate values at the mid-intertidal zone (Fig. 6A). Richness differed among exposure levels only at the high and mid-intertidal zones (high: $F_{2,150}=$ 

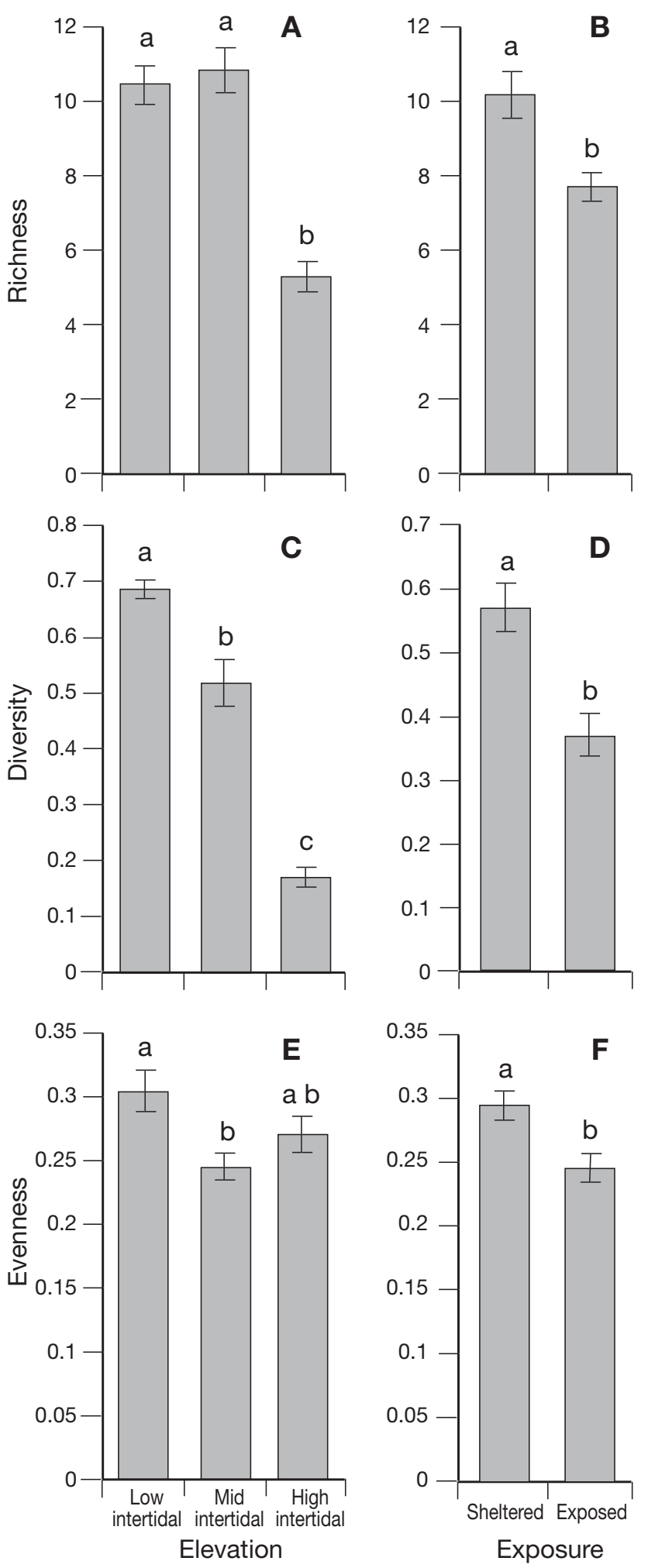

Fig. 3. Main effects for $(A, B)$ richness, $(C, D)$ diversity, and $(E, F)$ evenness (mean $\pm S E$ ) across $(A, C, E)$ vertical and $(B, D, F)$ horizontal environmental stress gradients at Sea Spray Shore (SS). In each graph, significant differences between means are indicated by different letters (see 'Results - Richness, diversity, and evenness at $\mathrm{SS}^{\prime}$ for $\mathrm{p}$-values)
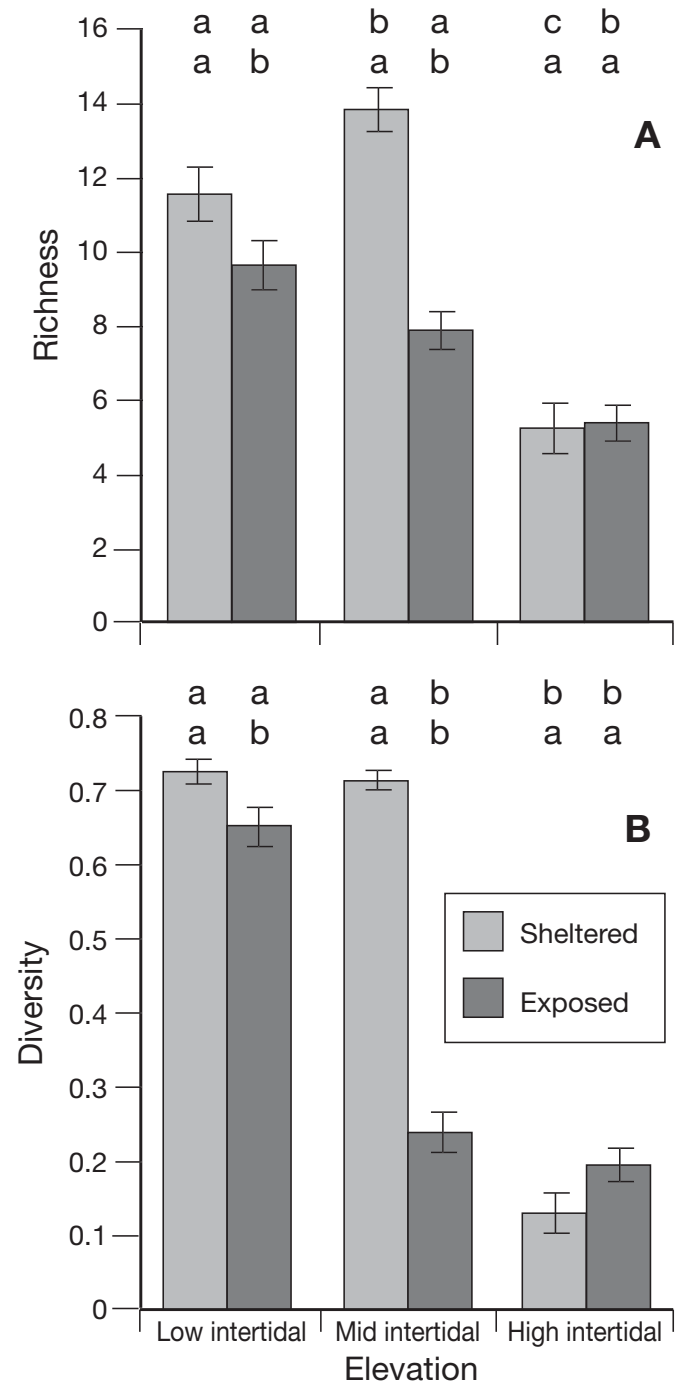

Fig. 4. Simple effects for (A) richness and (B) diversity across vertical and horizontal environmental stress gradients at Sea Spray Shore (SS). In each graph, the upper row of letters compares means for elevation levels separately for each exposure level, while the lower row compares means for exposure levels separately for each elevation. For each set of comparisons, significant differences between means are indicated by different letters (see 'Results - Richness, diversity, and evenness at $\mathrm{SS}^{\prime}$ for $\mathrm{p}$-values)

33.34, $\mathrm{p}<0.05$; mid: $\left.F_{2,150}=16.75, \mathrm{p}<0.05\right)$, being similar among exposures at the low zone $\left(F_{2,150}=1.93\right.$, $\mathrm{p}>0.05$; Fig. 6A). At the high intertidal zone, richness decreased $(p<0.001)$ from exposed to intermediateexposure areas, and increased $(p<0.001)$ from there to sheltered areas (Fig. 6A). At the mid-intertidal zone, richness was similar $(p=0.087)$ between sheltered and intermediate-exposure areas, and decreased $(\mathrm{p}<$ 0.01) on exposed areas (Fig. 6A). The contribution of elevation, exposure, and the elevation $\times$ exposure interaction to the total variability in richness was $40.7 \%, 11.6 \%$, and $8.8 \%$, respectively (61.1\% in total). 
Table 2. Abundance of taxa (percent cover $\pm \mathrm{SE} ; \mathrm{n}=20$ quadrats) across the elevation gradient (low, mid-, and high intertidal zones) on sheltered, intermediate-exposure and exposed areas at Tor Bay Provincial Park (TB). Blanks represent zero abundance

\begin{tabular}{|c|c|c|c|c|c|c|c|c|c|}
\hline \multirow{2}{*}{ Taxon } & \multicolumn{3}{|c|}{ - Sheltered - } & \multicolumn{3}{|c|}{ - Intermediate } & \multicolumn{3}{|c|}{ - Exposed - } \\
\hline & Low & Mid & High & Low & Mid & High & Low & Mid & High \\
\hline \multicolumn{10}{|l|}{ Seaweeds } \\
\hline Alaria esculenta & & & & & & & $1.1 \pm 1$ & 0 & 0 \\
\hline Ascophyllum nodosum & $79.65 \pm 7.7$ & $90.65 \pm 4.6$ & $48.75 \pm 6.97$ & $23.85 \pm 6.93$ & $27.9 \pm 7.02$ & $0.75 \pm 0.4$ & & $0.4 \pm 0.35$ & \\
\hline Calothrix sp. & & & & & & $0.88 \pm 0.85$ & & & $5.23 \pm 1.55$ \\
\hline Chondrus crispus & $36.6 \pm 6.47$ & $4.35 \pm 1.37$ & $0.03 \pm 0.03$ & $34.65 \pm 7.39$ & $1.88 \pm 0.67$ & & $26.15 \pm 4.38$ & $6.35 \pm 2.12$ & $0.03 \pm 0.03$ \\
\hline Chordaria flagelliformis & $0.33 \pm 0.3$ & & & & & & $3.45 \pm 1.39$ & $5.23 \pm 2.89$ & $0.68 \pm 0.34$ \\
\hline Cladophora rupestris & & & & & & & $0.35 \pm 1.39$ & $0.08 \pm 0.05$ & \\
\hline Cladophora sp. & $0.38 \pm 0.26$ & $0.1 \pm 0.1$ & & & $0.03 \pm 0.03$ & & & & \\
\hline Corallina officinalis & $17.03 \pm 4.84$ & $0.25 \pm 0.12$ & & $6.13 \pm 2.04$ & $0.03 \pm 0.03$ & & $30 \pm 6.1$ & $2.45 \pm 1.03$ & \\
\hline Devaleraea ramentacea & & & & & & & $1.33 \pm 0.46$ & $0.2 \pm 0.16$ & \\
\hline Dumontia contorta & $1.2 \pm 0.85$ & $0.05 \pm 0.05$ & & $0.63 \pm 0.41$ & $0.03 \pm 0.03$ & & & & \\
\hline Epiphytic brown algae & $5.75 \pm 1.48$ & $8.4 \pm 1.36$ & $1.03 \pm 0.45$ & $5.55 \pm 1.14$ & $9.75 \pm 2.01$ & $0.05 \pm 0.03$ & $16.2 \pm 4.1$ & $18.2 \pm 5.13$ & $0.5 \pm 0.25$ \\
\hline Filamentous turf & & & & & & $6.53 \pm 2.17$ & $7.7 \pm 2.55$ & $45.5 \pm 7.86$ & $9.03 \pm 3.18$ \\
\hline Fucus serratus & $1.55 \pm 0.72$ & & & & & & & & \\
\hline Fucus sp. & & $0.18 \pm 0.11$ & $2.28 \pm 0.62$ & $5.08 \pm 1.86$ & $3.88 \pm 1.62$ & $0.55 \pm 0.29$ & $48.3 \pm 8.86$ & $31.58 \pm 6.54$ & $4.33 \pm 1.66$ \\
\hline Fucus spiralis & & & & & & & & & $1.2 \pm 0.9$ \\
\hline Fucus vesiculosus & $2.2 \pm 1.11$ & $8.68 \pm 2.86$ & $17.5 \pm 3.95$ & $17.9 \pm 5.67$ & $14.3 \pm 4.34$ & & & & \\
\hline Green crust & $0.48 \pm 0.23$ & $7.48 \pm 2.43$ & $8.95 \pm 3.21$ & $3.38 \pm 0.61$ & $2.13 \pm 0.87$ & $0.38 \pm 0.14$ & & & $0.38 \pm 0.16$ \\
\hline Laminaria digitata & $6.35 \pm 3.97$ & & & & & & $0.8 \pm 0.75$ & & \\
\hline Laminaria longicruris & $0.85 \pm 0.64$ & & & & & & $1.1 \pm 0.65$ & & \\
\hline Laminaria saccharina & & & & & & & $0.85 \pm 0.6$ & & \\
\hline Lithothamnion sp. & $7.55 \pm 0.81$ & $3.88 \pm 1.06$ & & $3.48 \pm 1.18$ & $0.25 \pm 0.12$ & & $10.45 \pm 4.53$ & $0.8 \pm 0.42$ & \\
\hline Polysiphonia sp. & $0.43 \pm 0.24$ & $0.33 \pm 0.25$ & & & & & $10.28 \pm 1.89$ & $2.6 \pm 1.72$ & \\
\hline Porphyra sp. & & & & & & & $0.28 \pm 0.2$ & & \\
\hline Ralfsia sp. & & $1.13 \pm 0.51$ & $1.13 \pm 0.51$ & & & & & $61.2 \pm 7.92$ & \\
\hline Red crust & $9.7 \pm 3.67$ & $15.45 \pm 3.79$ & $10.05 \pm 3.3$ & $49.25 \pm 8.14$ & $60.05 \pm 8.21$ & $1.23 \pm 0.39$ & $34.95 \pm 8.6$ & $18.88 \pm 6.77$ & $29.45 \pm 6.62$ \\
\hline Rhizoclonium tortuosum & $0.15 \pm 0.15$ & & & & $0.15 \pm 0.15$ & & & & \\
\hline Rhodomela sp. & & & & & & & & $1.1 \pm 0.48$ & \\
\hline Scytosiphon sp. & & & & & & & & $7.75 \pm 2.71$ & $2.13 \pm 1.36$ \\
\hline Spongomorpha aeruginosa & & & & $0.03 \pm 0.03$ & & & $0.3 \pm 0.16$ & $2.45 \pm 0.67$ & $0.3 \pm 0.16$ \\
\hline Ulva intestinalis & & & & & & & & & $0.1 \pm 0.06$ \\
\hline Invertebrates & & & & & & & & & \\
\hline Amphipoda & $0.28 \pm 0.08$ & $0.58 \pm 0.08$ & $0.7 \pm 0.09$ & $0.38 \pm 0.05$ & $0.43 \pm 0.04$ & $0.15 \pm 0.05$ & $0.5 \pm 0.06$ & $0.28 \pm 0.06$ & $0.35 \pm 0.06$ \\
\hline Anomia simplex & $0.1 \pm 0.07$ & & & $0.1 \pm 0.06$ & & & $0.05 \pm 0.03$ & & \\
\hline Asterias sp. & $0.13 \pm 0.07$ & $0.23 \pm 0.09$ & & & & & & & \\
\hline Cancer irroratus & & & & & $0.05 \pm 0.05$ & & & & \\
\hline Cancersp. & & $0.03 \pm 0.03$ & & $0.18 \pm 0.11$ & & & & & \\
\hline Carcinus maenas & $0.1 \pm 0.1$ & & & & $0.15 \pm 0.11$ & & & & \\
\hline Clava multicornis & $0.03 \pm 0.03$ & & & & & & & & \\
\hline Coryphella sp. & & & & $0.03 \pm 0.03$ & & & & & \\
\hline Dynamena pumila & $6.2 \pm 1.74$ & $16.33 \pm 4.39$ & $3.23 \pm 1.28$ & $0.23 \pm 0.12$ & $1.03 \pm 0.4$ & & $0.13 \pm 0.07$ & $0.05 \pm 0.05$ & \\
\hline Electra sp. & & $3.2 \pm 2.47$ & & & & & & & \\
\hline Halichondria sp. & $0.43 \pm 0.26$ & & & $0.08 \pm 0.04$ & & & $0.35 \pm 0.22$ & & \\
\hline Halisarca sp. & $0.1 \pm 0.1$ & & & $0.05 \pm 0.05$ & & & & & \\
\hline Hiatella arctica & & & & $0.05 \pm 0.03$ & & & $0.15 \pm 0.05$ & & \\
\hline Idotea sp. & $0.15 \pm 0.06$ & $0.1 \pm 0.06$ & $0.03 \pm 0.03$ & $0.25 \pm 0.08$ & & & $0.05 \pm 0.03$ & & \\
\hline Lacuna vincta & $0.1 \pm 0.05$ & & & $0.28 \pm 0.06$ & & & $0.33 \pm 0.05$ & & \\
\hline Littorina littorea & $4.45 \pm 2.21$ & $1.45 \pm 0.4$ & $0.2 \pm 0.07$ & $4 \pm 0.71$ & $2.4 \pm 0.32$ & $0.43 \pm 0.05$ & $0.13 \pm 0.1$ & $0.43 \pm 0.11$ & $0.25 \pm 0.06$ \\
\hline Littorina obtusata & $0.2 \pm 0.07$ & $0.53 \pm 0.06$ & $0.75 \pm 0.11$ & $0.08 \pm 0.04$ & $0.48 \pm 0.08$ & & & $0.18 \pm 0.07$ & $0.08 \pm 0.04$ \\
\hline Littorina saxatilis & & & $0.28 \pm 0.06$ & & & $0.53 \pm 0.06$ & & & $0.68 \pm 0.17$ \\
\hline Membranipora sp. & $5.03 \pm 1.20$ & $0.4 \pm 0.1$ & & $2.7 \pm 0.72$ & $0.03 \pm 0.03$ & & $0.83 \pm 0.32$ & & \\
\hline Mytilus sp. & $0.08 \pm 0.04$ & $0.43 \pm 0.11$ & $1.15 \pm 0.32$ & $0.53 \pm 0.08$ & $0.5 \pm 0.15$ & $0.43 \pm 0.2$ & $0.45 \pm 0.11$ & $0.33 \pm 0.08$ & $0.28 \pm 0.08$ \\
\hline Nucella lapillus & $0.03 \pm 0.03$ & $0.08 \pm 0.05$ & $0.13 \pm 0.06$ & $0.65 \pm 0.11$ & $1.03 \pm 0.38$ & $0.03 \pm 0.03$ & $0.6 \pm 0.14$ & $0.15 \pm 0.07$ & $0.03 \pm 0.03$ \\
\hline Obelia sp. & $0.53 \pm 0.25$ & $0.93 \pm 0.24$ & $0.45 \pm 0.16$ & $1.3 \pm 0.58$ & $0.6 \pm 0.2$ & & $0.4 \pm 0.4$ & & \\
\hline Pagurus sp. & $0.38 \pm 0.15$ & & & & & & & & \\
\hline Semibalanus balanoides & $0.23 \pm 0.06$ & $1 \pm 0.22$ & $3.1 \pm 0.67$ & $0.75 \pm 0.11$ & $3.53 \pm 1.7$ & $2.13 \pm 0.58$ & $0.33 \pm 0.2$ & $0.48 \pm 0.11$ & $2.93 \pm 0.75$ \\
\hline Spirorbis spirillum & $1.13 \pm 0.38$ & & & & & & & & \\
\hline Tectura testudinalis & $0.25 \pm 0.09$ & $0.28 \pm 0.06$ & $0.05 \pm 0.03$ & $0.9 \pm 0.23$ & $0.18 \pm 0.07$ & & $0.48 \pm 0.14$ & $0.1 \pm 0.05$ & \\
\hline Urticina felina & & & & $0.03 \pm 0.03$ & & & $0.08 \pm 0.05$ & & \\
\hline Worms & $0.13 \pm 0.05$ & $0.43 \pm 0.04$ & $0.38 \pm 0.05$ & $0.08 \pm 0.04$ & $0.2 \pm 0.07$ & $0.18 \pm 0.07$ & & $0.28 \pm 0.11$ & $0.8 \pm 0.21$ \\
\hline
\end{tabular}



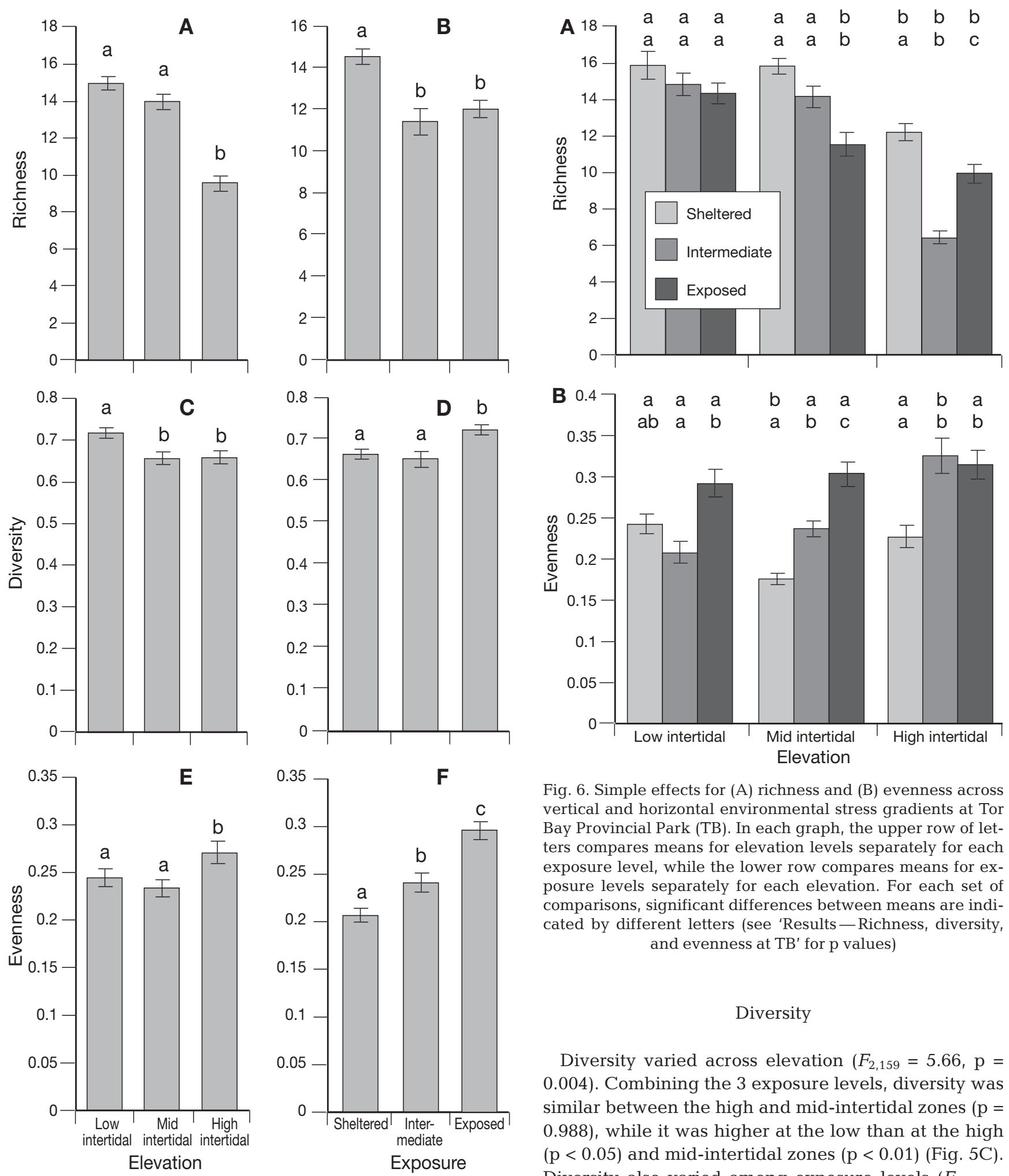

Fig. 6. Simple effects for (A) richness and (B) evenness across vertical and horizontal environmental stress gradients at Tor Bay Provincial Park (TB). In each graph, the upper row of letters compares means for elevation levels separately for each exposure level, while the lower row compares means for exposure levels separately for each elevation. For each set of comparisons, significant differences between means are indicated by different letters (see 'Results - Richness, diversity, and evenness at TB' for $p$ values)

\section{Diversity}

Diversity varied across elevation $\left(F_{2,159}=5.66, \mathrm{p}=\right.$ 0.004). Combining the 3 exposure levels, diversity was similar between the high and mid-intertidal zones $(\mathrm{p}=$ 0.988), while it was higher at the low than at the high $(\mathrm{p}<0.05)$ and mid-intertidal zones ( $<<0.01)$ (Fig. 5C). Diversity also varied among exposure levels $\left(F_{2,159}=\right.$ $6.11, \mathrm{p}=0.003$ ). Combining the 3 elevations, diversity was higher on exposed than on intermediate-exposure $(\mathrm{p}<0.005)$ and sheltered $(\mathrm{p}<0.05)$ areas, while it was similar $(p=0.807)$ between intermediate-exposure and sheltered areas (Fig. 5D). The elevation $\times$ exposure 
interaction was not significant $\left(F_{4,159}=0.82, \mathrm{p}=0.515\right)$. The contribution of elevation and exposure to the total variability in diversity was $5 \%$ and $5.4 \%$, respectively $(10.4 \%$ in total).

\section{Evenness}

Evenness varied across elevation $\left(F_{2,151}=10.28, \mathrm{p}<\right.$ 0.001). Combining the 3 exposure levels, evenness was higher at the high than at the mid- $(\mathrm{p}<0.001)$ and low $(\mathrm{p}<0.01)$ intertidal zones, while it was similar $(\mathrm{p}=$ 0.555) between the mid- and low zones (Fig. 5E). Evenness also varied among exposure levels $\left(F_{2,151}=\right.$ 29.78, p < 0.001). Combining the 3 elevations, evenness showed a monotonic decrease from exposed to intermediate-exposure $(p<0.01)$ to sheltered $(p<0.01)$ areas (Fig. 5F). The elevation $\times$ exposure interaction was also significant $\left(F_{4,151}=7.08, \mathrm{p}<0.001\right)$. Evenness differed among elevations only on sheltered and intermediate-exposure areas (sheltered: $F_{2,151}=7.67, \mathrm{p}<$ 0.05; intermediate: $\left.F_{2,151}=18.67, \mathrm{p}<0.05\right)$, but not on exposed areas $\left(F_{2,151}=0.67, \mathrm{p}>0.05\right)$. On sheltered areas, evenness was lower at mid- than at high $(\mathrm{p}<$ $0.005)$ and low ( $p<0.001)$ elevations. At intermediate exposure, evenness was higher at high than at mid$(p<0.001)$ and low ( $p<0.001)$ elevations (Fig. 6B). Evenness differed among exposure levels at the 3 elevations (high: $F_{2,151}=15.33, \mathrm{p}<0.05$; mid: $F_{2,151}=25.33$, $\mathrm{p}<0.05$; low: $\left.F_{2,151}=11.67, \mathrm{p}<0.05\right)$. At the high intertidal zone, evenness was similar $(p=0.894)$ between exposed and intermediate-exposure areas, while it was lower on sheltered than on exposed $(p<0.005)$ and intermediate-exposure ( $<<0.005$ ) areas (Fig. 6B). At the mid-intertidal zone, evenness showed a monotonic decrease from exposed to intermediate-exposure ( $p<0.001$ ) to sheltered ( $p<0.001$ ) areas (Fig. 6B). At the low intertidal zone, evenness was similar between exposed and sheltered areas $(p=0.054)$ and between intermediate-exposure and sheltered areas ( $p=0.224)$, while it was higher on exposed than on intermediateexposure areas $(p<0.001)$ (Fig. 6B). The contribution of elevation, exposure, and the elevation $\times$ exposure interaction to the total variability in evenness was $7.1 \%, 22 \%$, and $9.5 \%$, respectively (38.6\% in total).

\section{DISCUSSION}

The updated version (Bruno et al. 2003) of the ESM by Menge \& Sutherland (1987) predicts that highly stressful habitats should sustain a low species richness and diversity (again, richness and diversity have been used interchangeably). Across vertical gradients on rocky intertidal habitats, the strongest abiotic stress occurs at the high zone because of its frequent exposure to air due to tide dynamics (Raffaelli \& Hawkins 1996, Bertness \& Leonard 1997, Hacker \& Gaines 1997, Garbary 2007). The ESM also predicts that lower degrees of abiotic stress should result in increasing richness and diversity up to moderate stress levels (Fig. 1). Since harsh winter conditions prevent low year-round levels of stress from occurring in Nova Scotia, we had hypothesized that richness and diversity would be lowest at the high intertidal zone and would increase towards lower elevations. Our results at SS and TB matched such a pattern, thus providing support for ESM predictions. In fact, the very low richness (consisting mostly of the barnacle Semibalanus balanoides) found at high elevations at SS may place such habitats among the most stressful for intertidal life on rocky shores (see Bertness et al. 2006 for more examples). The negative relationship between richness and elevation was also reported for a tropical rocky shore (Lubchenco et al. 1984), suggesting a possibly common pattern for rocky intertidal habitats in general.

Across horizontal environmental gradients, our results matched predictions only at $\mathrm{SS}$, with a more complex pattern emerging at TB. High physical stress occurs in rocky intertidal habitats subjected to strong wave action (Denny \& Wethey 2001) and/or ice scour (Barnes 1999, Gutt 2001, Scrosati \& Heaven 2006). In agreement with ESM predictions, both richness and diversity were negatively related to wave/ice exposure at SS. At TB, however, richness did peak at wave-sheltered habitats, thus supporting the ESM, but diversity peaked at wave-exposed habitats. The spatial trend in evenness explains such a difference for TB. Diversity depends on richness and evenness, as both a higher number of taxa and a higher degree of similarity in abundance among taxa increase the probability of selecting 2 random individuals that belong to different taxa (Krebs 1999). The monotonic increase in evenness from sheltered to exposed habitats at TB was more pronounced than the increase in richness from exposed to sheltered habitats, as indicated by their respective magnitudes of effect. Thus, diversity at TB showed a spatial trend more similar to that for evenness. The consistent decrease in evenness from exposed to sheltered habitats appears to have resulted from the progressively increasing dominance of just one species, the fucoid seaweed Ascophyllum nodosum (Table 2). This species is predominant in wavesheltered habitats on North Atlantic rocky shores (Adey \& Hayek 2005, Cervin et al. 2005). Although it may displace other primary-space holders (Cervin et al. 2005), its large size and complex morphology creates microhabitat conditions that increase local species richness (Johnson \& Scheibling 1987). Fig. 5B shows such an increase in richness in sheltered habitats, but 
the apparently larger effect of A. nodosum on evenness promoted a decrease in diversity.

Our results indicate the importance of measuring richness and diversity separately. Past ESM research has often considered both variables as synonyms (Menge \& Sutherland 1987, Paine 1994, Hacker \& Gaines 1997, Bertness 2007). In other words, trends for richness and diversity were presumed to be the same across environmental stress gradients. They were the same across the vertical gradient at SS and TB and across the horizontal gradient at SS, but opposite across the horizontal gradient at TB. Other recent studies have also found dissimilarities (Kimbro \& Grosholz 2006). Mackey \& Currie (2001) differentiate between richness and diversity in an attempt to explain the variability existing in the literature in the shape of the diversity-disturbance relationship (disturbance being an extreme form of stress). They concluded that the differences in the shape of such a relationship depend on which variable is measured. Therefore, we suggest that trends in richness and diversity may differ to some extent across full environmental stress gradients. Future ESM studies should quantify richness, diversity, and evenness to understand under what conditions richness and diversity may show different trends, thus leading to updated theoretical synthesis.

Our study also contributes to the understanding of evenness trends across environmental stress gradients. This is relevant because evenness is not included in any version of the ESM, nor is it as common in the literature as richness and diversity (Mackey \& Currie 2001). Our initial assumption that wave-exposed habitats at TB represent the highest levels of stress for the NW Atlantic rocky intertidal biota may not be entirely accurate. Our water velocity measurements for exposed habitats at $\mathrm{TB}$, obtained in summer and autumn, are comparable to values obtained in spring at other exposed sites on the open Atlantic coast of Nova Scotia (Hunt \& Scheibling 2001). However, higher levels of stress are apparently reached when wave exposure combines with strong ice scour, such as on the Gulf of St. Lawrence coast (Scrosati \& Heaven 2006). Thus, our original prediction of an increase in evenness from exposed to sheltered habitats at TB might be more appropriate for a higher range of environmental stress. In fact, such a trend in evenness was observed at SS. Results matching our original prediction were also found in other systems. In intertidal cobble habitats from California, community evenness was inversely related to the intensity of disturbance (Kimbro \& Grosholz 2006). These results indicate that evenness should be investigated in ESM studies to determine under what conditions different trends may occur, and the potential impacts on diversity trends.
As implied above, the accurate determination of the local-scale range of environmental stress is relevant to ESM studies. The entire gradient of environmental stress across which a basic set of species can occur is rarely found locally on a given shore (Menge \& Sutherland 1987). To enable meaningful comparisons among studies, it is necessary to establish where the environmental range for a surveyed area falls in the entire stress gradient for a determined species pool. Overall environmental stress results from the combined, often synergistic, action of several abiotic factors; simultaneously quantifying the biologically relevant ones is the ideal approach. However, logistic limitations may allow for only one or a small subset of factors to be quantified, so biological traits (body temperature, photosynthetic performance, heat-shock proteins, mortality rates, RNA/DNA ratio; Dahlhoff 2004, Nielsen et al. 2006) are used as proxies for environmental stress. However, local adaptations may limit the utility of biological traits to infer stress differences between sites. Thus, the accurate determination of stress remains a challenge. Measures synthesizing the effects of key abiotic factors are needed, particularly when physical and physiological stresses vary spatially in opposite ways.

Finally, our study supports ESM predictions for richness also when comparisons are made between shores. We identified 38 taxa at SS, but 58 at TB. The intense ice scour occurring every winter on the Gulf of St. Lawrence coast (McKindsey \& Bourget 2001, Scrosati \& Heaven 2006) is infrequent on the open Atlantic coast. Fast ice (ice formed on the sea surface; Barnes 1999) does not form on the Atlantic coast, so local ice scour results only from the dynamics of the ice foot (ice formed on intertidal surfaces; Barnes 1999). Floating fragments of fast ice from the Gulf of St. Lawrence may reach the open Atlantic coast of mainland Nova Scotia, but such events are rare, without happening for years (Minchinton et al. 1997). Therefore, the higher richness at TB is consistent with the lower degree of physical stress there than at SS. While the highest stress levels for NW Atlantic rocky intertidal organisms are not commonly experienced on the open Atlantic coast of Nova Scotia, the same is true for relatively mild conditions, which are experienced more frequently farther south, in New England. Thus, consideration of the entire temperate coast of eastern North America seems necessary to observe the full environmental stress gradient (Fig. 1) in which the NW Atlantic rocky intertidal biota occurs. Because of their higher range of stress than most previously studied temperate shores, Nova Scotia shores are convenient model systems on which to test mechanisms explaining richness, diversity, and evenness trends, including changes in the relative importance of interspecific interactions across stress gradients. 
Acknowledgements. We are grateful to E. MacPherson and L. Eckersley for field assistance, and to 2 anonymous reviewers for comments on the manuscript. Funding was provided by grants to R.S. from the Canada Research Chair (CRC) program, the Canada Foundation for Innovation (CFI), the Natural Sciences and Engineering Research Council of Canada (NSERC), and the Saint Francis Xavier University Council for Research (UCR).

\section{LITERATURE CITED}

Adey WH, Hayek LC (2005) The biogeographic structure of the western North Atlantic rocky intertidal. Cryptogam Algol 26:35-66

Barnes DKA (1999) The influence of ice on polar nearshore benthos. J Mar Biol Assoc UK 79:401-407

Bell EC, Denny MW (1994) Quantifying 'wave exposure': a simple device for recording maximum velocity and results of its use at several field sites. J Exp Mar Biol Ecol 181: 9-29

Bennington CC, Thayne WV (1994) Use and misuse of mixedmodel analysis of variance in ecological studies. Ecology 75:717-722

Bertness MD (2007) Atlantic shorelines. Natural history and ecology. Princeton University Press, Princeton, NJ

Bertness MD, Leonard GH (1997) The role of positive interactions in communities: lessons from intertidal habitats. Ecology 78:1976-1989

Bertness MD, Trussell GC, Ewanchuk PJ, Silliman BR, Crain CM (2004) Consumer-controlled community states on Gulf of Maine rocky shores. Ecology 85:1321-1331

Bertness MD, Crain CM, Silliman BR, Bazterrica MC, Reyna MV, Hildago F, Kongo Farina J (2006) The community structure of western Atlantic Patagonian rocky shores. Ecol Monogr 76:439-460

Bruno JF, Stachowicz JJ, Bertness MD (2003) Inclusion of facilitation into ecological theory. Trends Ecol Evol 18: 119-125

Cervin G, Åberg P, Jenkins SR (2005) Small-scale disturbance in a stable canopy-dominated community: implications for macroalgal recruitment and growth. Mar Ecol Prog Ser 305:31-40

Crain CM, Bertness MD (2006) Ecosystem engineering across environmental gradients: implications for conservation and management. Bioscience 56:211-218

Dahlhoff EP (2004) Biochemical indicators of stress and metabolism: applications for marine ecological studies. Annu Rev Physiol 66:183-207

Denny M, Wethey D (2001) Physical processes that generate patterns in marine communities. In: Bertness MD, Gaines SD, Hay ME (eds) Marine community ecology. Sinauer, Sunderland, p 3-37

Fisheries and Oceans Canada (2007a) Temperature-salinity climatologies. Available at: www.mar.dfo-mpo.gc.ca/ science/ocean/tsdata.html

Fisheries and Oceans Canada (2007b) Marine environmental data services. Available at: www.meds-sdmm.dfo-mpo. gc.ca./meds/databases/wave/tdc_e.htm

Garbary DJ (2007) The margin of the sea: survival at the top of the tides. In: Seckbach J (ed) Algae and cyanobacteria of extreme environments. Springer-Verlag, Berlin (in press)

Gibson M (2003) Seashores of the Maritimes. Nimbus Publishing, Halifax

Gutt J (2001) On the direct impact of ice on marine benthic communities, a review. Polar Biol 24:553-564
Hacker SD, Gaines SD (1997) Some implications of direct positive interactions for community species diversity. Ecology 78:1990-2003

Harley CDG, Helmuth BST (2003) Local- and regional-scale effects of wave exposure, thermal stress, and absolute versus effective shore level on patterns of intertidal zonation. Limnol Oceanogr 48:1498-1508

Hay ME, Parker JD, Burkepile DE, Caudill CC, Wilson AE, Hallinan ZP, Chequer AD (2004) Mutualisms and aquatic community structure: the enemy of my enemy is my friend. Annu Rev Ecol Evol Syst 35:175-197

Heaven CS (2006) Patterns in rocky intertidal community structure on the northern and eastern shores of Nova Scotia. MSc dissertation, Saint Francis Xavier University, Antigonish

Hooper DU, Chapin FS, Ewel JJ, Hector A and 11 others (2005) Effects of biodiversity on ecosystem functioning: a consensus of current knowledge. Ecol Monogr 75:3-35

Howell DC (2002) Statistical methods for psychology. Duxbury, Pacific Grove, CA

Hunt HL, Scheibling RE (2001) Predicting wave dislodgment of mussels: variation in attachment strength with body size, habitat, and season. Mar Ecol Prog Ser 213:157-164

Johnson SC, Scheibling RE (1987) Structure and dynamics of epifaunal assemblages on intertidal macroalgae Ascophyllum nodosum and Fucus vesiculosus in Nova Scotia, Canada. Mar Ecol Prog Ser 37:209-227

Kimbro DL, Grosholz ED (2006) Disturbance influences oyster community richness and evenness, but not diversity. Ecology 87:2378-2388

Krebs CJ (1999) Ecological methodology. Benjamin Cummings, Menlo Park, CA

Lubchenco J, Menge BA, Garrity SD, Lubchenco PJ and 5 others (1984) Structure, persistence, and role of consumers in a tropical rocky intertidal community (Taboguilla Island, Bay of Panama). J Exp Mar Biol Ecol 78: $23-73$

Mackey RL, Currie DJ (2001) The diversity-disturbance relationship: is it generally strong and peaked? Ecology 82: 3479-3492

Martínez AJ (2003) Marine life of the North Atlantic: Canada to New England. Aqua Quest Publications, New York

McKindsey CW, Bourget E (2001) Diversity of a northern rocky intertidal community: the influence of body size and succession. Ecology 82:3462-3478

Menge BA (2004) Bottom-up/top-down determination of rocky intertidal shorescape dynamics. In: Polis GA, Power ME, Huxel GR (eds) Food webs at the landscape level. University of Chicago Press, Chicago, IL, p 62-81

Menge BA, Branch GM (2001) Rocky intertidal communities. In: Bertness MD, Gaines SD, Hay ME (eds) Marine community ecology. Sinauer, Sunderland, p 221-251

Menge BA, Sutherland JP (1987) Community regulation: variation in disturbance, competition, and predation in relation to environmental stress and recruitment. Am Nat 130:730-757

Menge BA, Olson AM, Dahlhoff EP (2002) Environmental stress, bottom-up effects, and community dynamics: integrating molecular-physiological and ecological approaches. Integr Comp Biol 42:892-908

Minchinton TE, Scheibling RE, Hunt HL (1997) Recovery of an intertidal assemblage following a rare occurrence of scouring by sea ice in Nova Scotia, Canada. Bot Mar 40:139-148

Nielsen KJ, Blanchette CA, Menge BA, Lubchenco J (2006) Physiological snapshots reflect ecological performance of the sea palm, Postelsia palmaeformis (Phaeophyceae), 
across intertidal elevation and exposure gradients. J Phycol 42:548-559

Paine RT (1994) Marine rocky shores and community ecology: an experimentalist's perspective. In: Kinne O (ed) Excellence in ecology, Book 4. International Ecology Institute, Oldendorf/Luhe

Payne LX, Schindler DE, Parrish JK, Temple SA (2005) Quantifying spatial pattern with evenness indices. Ecol Appl 15:507-520

Pollock LW (1998) A practical guide to the marine animals of northeastern North America. Rutgers University Press, New Brunswick, NJ

Quinn GP, Keough MJ (2002) Experimental design and data analysis for biologists. Cambridge University Press, Cambridge

Raffaelli D, Hawkins S (1996) Intertidal ecology. Chapman \& Hall, London

Russell R, Wood SA, Allison G, Menge BA (2006) Scale, environment, and trophic status: the context dependency of community saturation in rocky intertidal communities. Am Nat 167:E158-E170

Saucier FJ, Roy F, Gilbert D, Pellerin P, Ritchie H (2003) Modeling the formation and circulation processes of water

Editorial responsibility: Howard Browman (Associate Editorin-Chief), Storebø, Norway masses and sea ice in the Gulf of St. Lawrence, Canada. J Geophys Res 108, C8, 3269, doi:10.1029/2000JC000686 Scrosati R (2005) Review of studies on biomass-density relationships (including self-thinning lines) in seaweeds: main contributions and persisting misconceptions. Phycol Res 53:224-233

Scrosati R, Heaven C (2006) Field technique to quantify intensity of scouring by sea ice in rocky intertidal habitats. Mar Ecol Prog Ser 320:293-295

Sears JR (1998) NEAS keys to the benthic marine algae of the northeastern coast of North America from Long Island Sound to the Strait of Belle Isle. Northeast Algal Society, Dartmouth, MA

Villalard-Bohnsack M (2003) Illustrated key to the seaweeds of New England. The Rhode Island Natural History Survey, Kingston, RI

Worm B, Barbier EB, Beaumont N, Duffy JE and 10 others (2006) Impacts of biodiversity loss on ocean ecosystem services. Science 314:787-790

Wright JP, Jones CG, Boeken B, Shachak M (2006) Predictability of ecosystem engineering effects on species richness across environmental variability and spatial scales. J Ecol 94:815-824

Submitted: February 23, 2007; Accepted: May 28, 2007

Proofs received from author(s): June 19, 2007 